\title{
Knowledge of Aceh Entrepreneurs about Capital Market
}

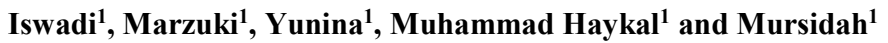 \\ \{iswadi@unimal.ac.id ${ }^{1}$, marzuki@unimal.ac.id ${ }^{2}$, yunina@unimal.ac.id ${ }^{3}$, $\underline{\text { mhaykal@unimal.ac.id }}^{4}$ \\ mursidah.usman31@gmail.com ${ }^{5}$ \}
}

${ }^{1}$ Faculty of Economic and Business, Universitas Malikussaleh Lhokseumawe, Indonesia

\begin{abstract}
This study aims to analyze the knowledge of Aceh entrepreneurs about the capital market and the factors that influence the increase in understanding of entrepreneurs about the capital market. This study is analyzed using a quantitative descriptive approach. This research sample is 120 Acehnese entrepreneurs. The sampling technique used is Judgment sampling. The results of the study show that the knowledge of Aceh entrepreneurs about the capital market is still low. Acehnese entrepreneurs do not understand the capital market so they are not interested in investing in the capital market. Seminars, stock game simulations and socialization of the capital market increase the knowledge of entrepreneurs and the understanding of the capital market. As a result, the desire of entrepreneurs to invest in the capital market also increases. The results of this study provide empirical evidence to policymakers about the need for capital market socialization for Aceh entrepreneurs and investment products in the capital market.
\end{abstract}

Keyword: Knowledge, Entrepreneur, Capital Market

\section{Introduction}

The capital market trades debt securities and shares for the long-term (Candra, 2009). Today, the capital market has become a nerve center for economic finance in various countries (Muklis, 2016). Therefore, the capital market is important for the economy of states because of its function as a means of funding for companies and a free of charge public investment in financial instruments (Spaseska, et al, 2016 ; Nasution, 2015).

The interest of investing in Indonesian society in the capital market is still low, only about $0.5 \%$ of the total population (Tarigan, 2013). Whereas, the growth of the middle-class society in Indonesia is fast, but this growth is not in line with the increase of public interest to invest in the capital market. This happens because the growth of the middle class society is not supported by adequate knowledge about the procedures for investing in the capital market (Muklis, 2016). As a result, people prefer short-term investments such as saving at a bank compared to investing in long-term financial assets. For this reason, it is necessary to provide sustainable education for the public about capital market investment (Tarigan, 2013). (Supriadi \& Hariyanto, 2017) on their research shows that Indonesian investor knowledge about capital markets is still low. Therefore, this study was conducted to determine the level of knowledge of Aceh entrepreneurs and their understanding of the capital market and investment in the capital market. Aceh is suspected that its entrepreneurs do not have a good understanding of the capital market because it is located in the westernmost tip of Indonesia. As a consequence, they do not want to invest their funds in the capital market. 


\section{Literature Review}

The investment decision of somebody on an asset is determined by the level of knowledge and understanding of the asset itself. Knowledge is needed to avoid losses and obtain maximum returns from investments (Kusmawati, 2011; Malik, 2017). The knowledge of investors in investment instruments greatly affects investment interests (Yuliati, 2011). Likewise, the investments in the capital market where the investors need to have knowledge about the capital market and investment products offered in the capital market.

The decisions of Investors are determined by their knowledge of investment techniques and risk perception. Knowledge has an important role in increasing investor interest to invest in the capital market (Khotimah, et al, 2011). The lack of public knowledge about investment in the capital market causes their low participation in investing in the capital market (Muklis, 2016). Insufficient knowledge about the capital market makes investors uninterested in investing (Hossen, et al, 2014). Information about investment products chosen by investors is important for making the right investment decisions.

Several previous studies in several countries showed that public knowledge about capital markets is low. Ganapathi research, (2014) in India proved that the public was aware of investing in the capital market did not have sufficient knowledge about investing in the capital market. Furthermore, the Acquah-sam \& Salami, (2013) research found that the majority of Ghanaian people had little knowledge about the capital market activities. The same finding was also proven in Bangladesh, the majority of investors did not have the fundamental knowledge to invest in the capital market. The lack of knowledge of investors on investment procedures results in low investor interest in investing in the capital market (Yuliati, 2011; Acquah-sam and Salami, 2013; Supriadi and Hariyanto, 2017).

\section{Methodology}

The unit of observation of this study are entrepreneurs in 8 districts/cities in Aceh which are included Pidie Jaya Regency, Pidie Regency, Aceh Besar Regency, Banda Aceh City, West Aceh Regency, Nagan Raya Regency, South Aceh Regency, and Subulussalam City. The sampling technique used is judgment sampling. The amount of sample is 120 entrepreneurs with 15 entrepreneurs distribution per district/city.

\subsection{Method of collecting data}

This research data are obtained through a closed questionnaire measured by a Likert scale. The scale values used are 5 (strongly agree), 4 (agree), 3 (neutral), 2 (disagree), and 1 (strongly disagree).

\subsection{Data Analysis Method}

This study uses a quantitative descriptive approach. The researchers try to identify the knowledge and understanding of Acehnese entrepreneurs about investing in the capital market. Frequency tests are used to measure the perception of respondents. 


\section{Result And Discussion}

\subsection{Characteristics of Respondents}

The characteristics of respondents analyzed in this study include age, gender, education, and experience of respondents such as described in table 1 below:

Table 1. Respondents Characteristics

\begin{tabular}{|c|c|c|c|}
\hline No & Indicator & Frequency & $\begin{array}{l}\text { Percentage } \\
(\%)\end{array}$ \\
\hline 1. & $\begin{array}{l}\text { Age (in } \\
\text { years) }\end{array}$ & & \\
\hline & $20-30$ & 23 & 19,2 \\
\hline & $31-40$ & 53 & 44,2 \\
\hline & $>40$ & 44 & 36,6 \\
\hline & Total & 120 & 100,0 \\
\hline 2. & Gender & & \\
\hline & Male & 91 & 75,8 \\
\hline & Female & 29 & 24,2 \\
\hline & Total & 120 & 100,2 \\
\hline 3. & Education & & \\
\hline & $\begin{array}{l}\text { Senior } \\
\text { High } \\
\text { School }\end{array}$ & 59 & 49,2 \\
\hline & D3 & 6 & 5,0 \\
\hline & S1 & 38 & 31,7 \\
\hline & $\mathrm{S} 2$ & 7 & 5,8 \\
\hline & S3 & 10 & 8,3 \\
\hline & Total & 120 & 100,0 \\
\hline 4. & $\begin{array}{l}\text { Experience } \\
\text { (in years) }\end{array}$ & & \\
\hline & 3 & 28 & 23,3 \\
\hline & 4 & 9 & 7,5 \\
\hline & $>5$ & 83 & 69,2 \\
\hline & Total & 120 & 100,0 \\
\hline
\end{tabular}

Based on table 1 above, respondents with age of $20-30$ years are 23 people $(19.2 \%)$, the respondents with age 31-40 are 53 people (44.2\%), and the respondents over the age of 40 are 44 people $(36,6,3 \%)$. Based on the gender, 91 entrepreneurs $(75.8 \%)$ and are the majority respondents in the study, while the remaining 29 entrepreneurs $(24.2 \%)$ are taxable entrepreneurs with the female gender.

Based on 120 respondents, taxable entrepreneurs who have the last level of high school/equivalent education dominates 59 respondents $(49.2 \%)$. The second highest numbers of respondents who have the last education are 38 graduates of S1 education $(31.7 \%)$. The next is a taxable businessman with a final education in strata 3, stratum 2, and Diploma 3, each with 10 people $(8.3 \%), 7$ people $(5.8 \%)$, and 6 people $(5 \%)$. 
Based on the experience of running a business, 83 entrepreneurs (69.2\%) have experiences more than 5 years. The entrepreneurs with 3 years experience are 28 respondents $(23.3 \%)$ and the entrepreneurs with 4 years of work experience are 9 respondents $(7.5 \%)$. Overall, it shows that the Aceh Taxable Entrepreneurs already have a good experience in running their business well.

\subsection{Knowledge of Entrepreneurs about the Capital Market}

Entrepreneur knowledge about capital markets is measured through questions about the interest of entrepreneurs to invest in the capital market because of their knowledge and understanding, socialization and seminars on capital markets to increase entrepreneurs knowledge about capital markets.

\subsection{Entrepreneurs are not interested in investing in the Capital Market}

Attractiveness is a determinant for entrepreneurs to choose to invest in the capital market. $41(34.2 \%)$ entrepreneurs agree and 9 (7.5\%\%) entrepreneurs strongly agreed that they are not interested in investing in the capital market because they lack knowledge and understanding. $36(30 \%)$ entrepreneurs are neutral in investing in the capital market. Only a small percentage of entrepreneurs have the possibility of being interested in investing in the capital market. $29(24.2 \%)$ entrepreneurs disagree and 5 (4.25\%) entrepreneurs strongly disagree that they are not interested in investing in the capital market. Table 2 below shows the disinterest of Aceh entrepreneurs to invest in the capital market.

Table 2. Ketidaktertarikan Pengusaha Untuk Berinvestasi Di Pasar Modal

\begin{tabular}{lllll}
\hline & Freq & $\begin{array}{l}\text { Valid } \\
\text { \% }\end{array}$ & $\begin{array}{l}\text { Cumulative } \\
\text { \% }\end{array}$ \\
\hline $\begin{array}{l}\text { Strongly } \\
\text { Disagree }\end{array}$ & 5 & 4.2 & 4.2 & 4.2 \\
\hline Disagree & 29 & 24.2 & 24.2 & 28.3 \\
\hline Neutral & 36 & 30.0 & 30.0 & 58.3 \\
\hline Agree & 41 & 34.2 & 34.2 & 92.5 \\
\hline Strongly agree & 9 & 7.5 & 7.5 & 100.0 \\
\hline Total & 120 & $\begin{array}{l}100 . \\
0\end{array}$ & 100.0 & \\
\hline
\end{tabular}

\subsection{Socialization of the Capital Market}

Socialization of the capital market increases the knowledge of entrepreneurs about the capital market and increases interest in investing in products offered in the capital market. 54 $(45 \%)$ entrepreneurs agree and $12(10 \%)$ entrepreneurs strongly agree that the capital market socialization increases the knowledge and interest of entrepreneurs to invest in the capital market. $49(40.8 \%)$ entrepreneurs are neutral. The following table 3 shows the answers of Aceh entrepreneurs about the capital market socialization in to increase knowledge and interest in investing in the capital market. 
Table 3. Capital Market Socialization

\begin{tabular}{lllll}
\hline & Freq & $\mathbf{\%}$ & $\begin{array}{l}\text { Valid } \\
\mathbf{\%}\end{array}$ & $\begin{array}{l}\text { Cumulative } \\
\mathbf{\%}\end{array}$ \\
\hline Disagree & 5 & 4.2 & 4.2 & 4.2 \\
\hline Neutral & 49 & 40.8 & 40.8 & 45.0 \\
\hline Agree & 54 & 45.0 & 45.0 & 90.0 \\
\hline $\begin{array}{l}\text { Strongly } \\
\text { agree }\end{array}$ & 12 & 10.0 & 10.0 & 100.0 \\
\hline Total & 120 & 100.0 & 100.0 & \\
\hline
\end{tabular}

\subsection{Capital Market Seminar}

On average, entrepreneurs have a perception that seminars on capital markets can improve their understanding of the capital market. 59 (49.2\%) entrepreneurs agree and 20 $(16.7 \%)$ entrepreneurs strongly agree that the seminar on capital markets provide an adequate understanding of the capital market. Table 4 below shows the answers of Aceh entrepreneurs about capital market seminars and their contribution to the increase of understanding of the capital market

Table 4. Capital Market Seminar

\begin{tabular}{lllll}
\hline & \multicolumn{2}{c}{ Freq \% } & Valid & $\begin{array}{l}\text { Cumulative } \\
\text { \% }\end{array}$ \\
\hline Disagree & 2 & 1.7 & 1.7 & 1.7 \\
\hline Neutral & 4 & 3.3 & 3.3 & 5.0 \\
\hline Agree & 35 & 29.2 & 29.2 & 34.2 \\
\hline $\begin{array}{l}\text { Strongly } \\
\text { agree }\end{array}$ & 59 & 49.2 & 49.2 & 83.3 \\
\hline Total & 20 & 16.7 & 16.7 & 100.0 \\
\hline Disagree & 120 & 100.0 & 100.0 & \\
\hline
\end{tabular}

\subsection{Simulation of Stock Games}

The introduction of capital markets to entrepreneurs can be done through stock games. Stock games increase the knowledge of entrepreneurs about capital markets and make it easier for them to transact in the capital market. $43(35.8 \%)$ entrepreneurs agree and $10(8.3 \%)$ entrepreneurs strongly agree that the stock game simulation makes it easier for entrepreneurs to transact in the capital market. The following table 5 illustrates the answers of entrepreneur to stock game simulations to make it easier for entrepreneurs to transact in the capital market.

Tabel 5. Stock Game Simulation

\begin{tabular}{|c|c|c|c|c|}
\hline & Freq & $\%$ & Valid \% & $\begin{array}{r}\text { Cumulative } \\
\%\end{array}$ \\
\hline Disagree & 8 & 6.7 & 6.7 & 6.7 \\
\hline Neutral & 59 & 49.2 & 49.2 & 55.8 \\
\hline Agree & 43 & 35.8 & 35.8 & 91.7 \\
\hline $\begin{array}{l}\text { Strongly } \\
\text { agree }\end{array}$ & 10 & 8.3 & 8.3 & 100.0 \\
\hline Total & 120 & 100.0 & 100.0 & \\
\hline
\end{tabular}


There needs to be an effort to increase the knowledge of investors and understanding of securities investments (Supriadi and Hariyanto, 2017) so as to increase interest in investing in the capital market. In accordance with (Carretta et al., 2006) findings, investor interest drives the volume of stock trading in the capital market. Socialization, seminars, and education about the capital market can increase the knowledge of entrepreneurs about investing in the capital market.

\section{Conclusions}

This research is conducted on 120 taxable entrepreneurs in Aceh. The results of the study show that the knowledge and understanding of Aceh entrepreneurs about the capital market and investment in the capital market are low. It causes them to be less interested in investing in the capital market. Socialization and seminars on the capital market can improve the understanding and interest of entrepreneurs to invest in the capital market.

This study implies the need for socialization, holding seminars, and education about capital markets to encourage local entrepreneurs, especially Aceh in investing in stocks, bonds and other derivative securities in the capital market. Nowadays, the upper middle-class society in Indonesia which invests in the capital market is only around 5.5\% (Muklis, 2016). In addition, subsequent studies need to expand the object of research to the non-entrepreneur sector and implement focus group discussions to deepen the analysis of knowledge, understanding, and factors that can increase public knowledge and understanding of investment in the capital market.

\section{References}

[1] Acquah-sam, E. and Salami, K. (2013) 'Knowledge and Participation in Capital Market Activities: The Ghanaian Experience', International Journal of Scientific Research in Education, 6(June), pp. 189-203.

[2] Candra, T. (2009) Pasar Modal dan Karakteristik Investor Indonesia: Kasus Bursa Efek Indonesia. Riau: Sekolah Tinggi Ilmu Komputer Riau Pekan Baru.

[3] Carretta, A., Farina, V., Graziano, E. A. and Reale, M. (2006) Does investor attention influence stock market activity? The case of spin-off deals, Munich Personal RePEc Archive. MPRA Paper No. 33545. doi: http://dx.doi.org/10.1159/000487109.

[4] Ganapathi, R. (2014) 'Public Awareness Towards Capital Market Investment With Special Reference To Jrf Securities Limited , Hyderabad', 1(1), pp. 9-18.

[5] Hossen, M., Shareef, A. N. M., Hasan, M. N. and Sarani, P. (2014) 'Fundamentals Knowledge of Investor and Its Influence on Investment in Capital Market-A Study from Dhaka Stock Exchange', Research Journal of Finance and Accounting, 5(24), pp. 2222-2847.

[6] Khotimah, H., Warsini, S. and Nuraeni, Y. (2011) 'Pengaruh Sosialisasi dan Pengetahuan Terhadap Minat Investor Pada Efek Syariah di Pasar Modal (Survei Pada Nasabah PT Danareksa Sekuritas Cabang FE-UI Depok)', Account, pp. 423-433.

[7] Kusmawati, K. (2011) 'Pengaruh Motivasi Terhadap Minat Berinvestasi Di Pasar Modal Dengan Pemahaman Investasi Dan Usia Sebagai Variabel Moderat', Jurnal Ekonomi dan Informasi Akuntansi (JENIUS), 1(2), pp. 103-117. Available at: http://news.palcomtech.com/wp-content/uploads/2012/01/KUSMAWATIJE01022011.pdf.

[8] Malik, A. D. (2017) 'Melalui Bursa Galeri Investasi Uisi', 3(1), pp. 61-84. 
[9] Muklis, F. (2016) 'Perkembangan Dan Tantangan Pasar Modal', Lembaga keuangan dan Perbankan, 1(1), pp. 1-12.

[10] Nasution, Y. S. J. (2015) 'Peranan Pasar Modal Dalam Perekonomian Negara', Human Falah, 2(1), pp. 95-112.

[11] Spaseska, T., Risteska, A., Vitanova, G., Odzaklieska, D. and Risteska, F. (2016) 'Analysis of knowledge about capital market activities in Republic of Macedonia', Ekonomika, 62(2), pp. 71-83. doi: 10.5937/ekonomika1602071S.

[12] Supriadi, F. and Hariyanto, D. (2017) 'Faktor Pertimbangan Masyarakat Memilih Daftar Efek Syariah', Jurnal Manajemen MOTIVASI, 13(No. 1), pp. 802-806.

[13] Tarigan, R. E. (2013) 'Peranan Sistem Informasi dengan Online Trading Terhadap Pertumbuhan Pasar Modal di Indonesia Teori Investasi’, (27), pp. 803-811.

[14] Yuliati, L. (2011) 'Faktor-faktor yang mempengaruhi minat masyarakat berinventasi sukuk', Walisongo, 19(1), pp. 103-126. 